\title{
Chemical and isotopic composition of fumarolic gases at Iwate volcano, Japan, during and after seismic activity in 1998: implications for the modification of ascending volcanic gases
}

\author{
Takeshi Ohba ${ }^{1}$, Kenji Nogami ${ }^{2}$, Jun-ichi Hirabayashi ${ }^{2}$, Takeshi Sawa ${ }^{2}$, Kohei Kazahaya ${ }^{3}$, \\ Noritoshi Morikawa ${ }^{3}$, Michiko Ohwada ${ }^{3}$ \\ ${ }^{1}$ Tokai University, School of Science, Department of Chemistry, Kanagawa, Japan \\ ${ }^{2}$ Volcanic Fluid Research Center, Tokyo Institute of Technology, Gunma, Japan \\ ${ }^{3}$ Geological Survey of Japan, National Institute of Advanced Industrial Science and Technology, Tsukuba, Japan
}

\author{
Article history \\ Received December 9, 2010; accepted May 16, 2011. \\ Subject classification: \\ Gases, Magmas, Volcano monitoring, Hydrothermal systems.
}

\section{ABSTRACT}

In 1998, there were many volcanic earthquakes recorded at Iwate volcano, Japan. Although an eruption was anticipated, it never occurred. Fumarolic gases were sampled at the volcano on six occasions during 1998 and 1999, and were analyzed for their chemical compositions and isotope ratios. The fumarolic gases were again sampled in 2004 and 2006, after the period of seismic activity. The $\mathrm{HCl}$ concentrations and isotope ratios of the $\mathrm{H}_{2} \mathrm{O}$ in the gas samples collected from an active geothermal area at the volcano were high in 1998 and 1999, but decreased significantly after 2004, irrespective of the relatively stable concentrations of $\mathrm{CO}_{2}$ and sulfurbearing gases. A notable feature of the fumarolic gases is the high isotope ratio of $\mathrm{H}_{2} \mathrm{O}$, similar to that of pure magmatic gas, which is typical of andesitic volcanoes, although the temperature at the outlet was less than $146^{\circ} \mathrm{C}$ in the present case. These features can be explained if the enthalpy of the magmatic gas was equivalent to that of water vapor at $252^{\circ} \mathrm{C}$ to $370^{\circ} \mathrm{C}$ under a pressure of 1 bar. The correlations observed among $\mathrm{CO}_{2} / \mathrm{H}_{2} \mathrm{O}$ and $\mathrm{HCl} / \mathrm{H}_{2} \mathrm{O}$, and the $\delta^{18} \mathrm{O}$ values of the fumarolic gases suggest partial condensation of $\mathrm{H}_{2} \mathrm{O}$ vapor during the ascent of the volcanic gas to the surface. The estimated $\mathrm{CO}_{2} / \mathrm{H}_{2} \mathrm{O}$ molar ratio of the magmatic gas was 0.008 , which is less than the 0.03 reported previously for magmatic gas sampled during an effusive eruption at Unzen volcano, Japan. These data suggest that the magma at Iwate volcano is depleted in volatiles, because $\mathrm{CO}_{2}$ is preferentially degassed from the silicate melt relative to $\mathrm{H}_{2} \mathrm{O}$. Such depletion in $\mathrm{CO}_{2}$ might explain the failed eruption at Iwate volcano in 1998.

\section{Introduction}

Fumarolic gases generally include volatiles that are emitted from degassing magma; consequently, the chemical and isotopic compositions of such gases can provide information on the degassing magma. However, the chemical and isotopic compositions of the gases can be modified during the ascent to the surface, due to, for example, contamination by ground water, condensation of water vapor, and removal of acidic components, such as $\mathrm{HCl}$.

In 1998, many volcanic earthquakes occurred at Iwate volcano, Japan. However, although an eruption was anticipated, it never occurred. During and after this period of volcanic seismicity, we sampled fumarolic gases at the volcano and measured their chemical and isotopic compositions. In this study, we investigate the processes that acted to modify the chemical compositions and isotope ratios of these fumarolic gases, and we estimate the $\mathrm{CO}_{2} / \mathrm{H}_{2} \mathrm{O}$ ratios of the magmatic gases. The modification process is quantitatively modeled assuming simple physicochemical processes, which successfully reproduce the observed variations in the chemical and isotopic compositions of these fumarolic gases.

\subsection{Iwate volcano}

Iwate volcano is an active volcano in northern Honshu, Japan (Figure 1). The volcano has two topographic peaks and it is divided into its western and eastern parts, which are centered around Onawashiro crater (Figure 1, O) and Yakushidake crater (Figure 1, Y), respectively. Itoh and Doi [2005] investigated the development of Iwate volcano. The eastern part is younger than the western part, and its surface layer was deposited over the past 7,000 years. An eruption occurred at the outer rim of the Yakushidake crater in 1732, which produced lava flow. The eastern part contains limited geothermal activity. A weak and diffusive steam discharge occurred at point $\mathrm{H}$ in Figure 1, without any apparent sulfurbearing gases. The western part is relatively old, with the most recent lava from the Onawashiro crater estimated to be older than $30 \mathrm{ka}$ [Itoh and Doi 2005]. The western part is characterized by intensive geothermal activity that is 


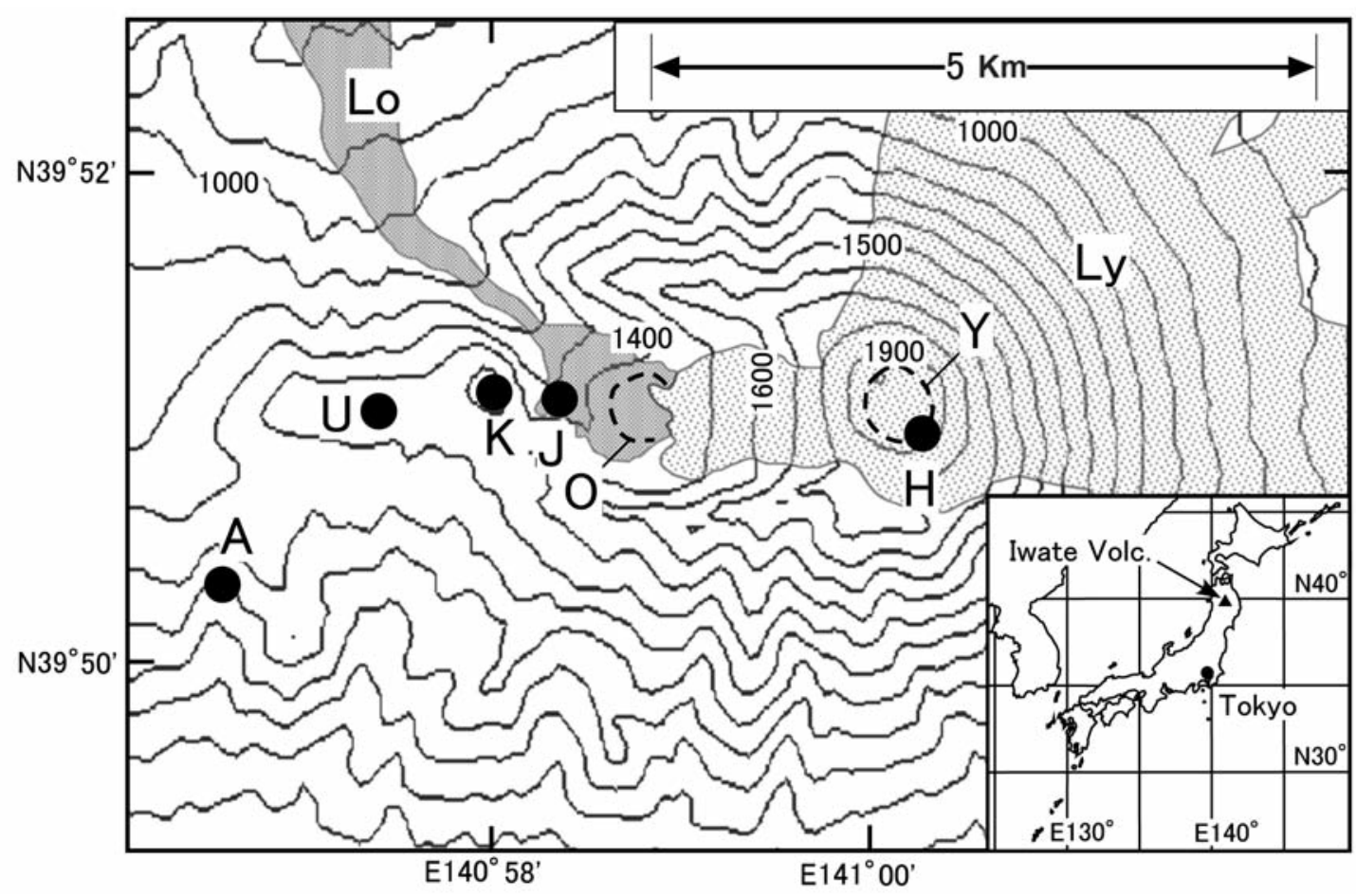

Figure 1. Topographic map of Iwate volcano (contour interval, $100 \mathrm{~m}$; altitude, meters above sea level). Inset, location of the volcano. Dashed curves $\mathrm{O}$ and Y, outer rims of the Onawashiro and Yakushidake craters, respectively. Shaded areas Lo and Ly, distribution of the lava flows from the Onawashiro and Yakushidake craters, respectively. Letters H (Higashi iwate), J (Ojigokudani), K (Kurokura), U (Ubakura), and A (Amihari), locations of geothermal areas from which the fumarolic gases were collected. At site $\mathrm{J}\left(39^{\circ} 51^{\prime} 05^{\prime \prime} \mathrm{N}, 140^{\circ} 58^{\prime} 21^{\prime \prime} \mathrm{E}\right)$, hot spring water was also collected. The area with altered soil at site J measured about $100 \mathrm{~m}$ (north-south) by $75 \mathrm{~m}$ (east-west). Intense fumarolic activity was noted at J, including a strong smell of sulfur-bearing gases (also detected at site A). At sites $\mathrm{H}, \mathrm{K}$ and $\mathrm{U}$, in contrast, sulfur-bearing gases were not smelt when sampling the fumarolic gases.

concentrated in four areas (Figure 1, J, K, U and A). At site J, in particular, there was a strong smell of sulfur-bearing gas. As the most recent volcanic activity, a steam driven explosive eruption was observed at site J in 1919.

About 300,000 people live in Morioka city, which is located $20 \mathrm{~km}$ southeast of Iwate volcano, and a north-south express highway is located $9 \mathrm{~km}$ east of Iwate volcano. During an eruption at Yakushidake crater in 1686, houses near Iwate volcano were affected by ash deposits and a lahar. Any future eruption at Iwate volcano poses serious risk to nearby residents and infrastructure.

Iwate volcano is monitored continuously by the Japan Meteorological Agency, in terms of its seismicity and crustal deformation (tiltmeter and GPS), but its fumarolic gases are not monitored. In terms of the geochemistry of the fumarolic gases at Iwate volcano, only Noguchi et al. [1961] have reported on the chemical composition of the gas and sublimate within the Yakushidake crater.

Miura et al. [2000] reported deformation of the volcanic body at Iwate volcano in 1998, which was attributed to the intrusion of magma at a depth of $3 \mathrm{~km}$ beneath the western part. From May to September 1998, many volcanic earthquakes were recorded beneath the region covered by points $\mathrm{O}, \mathrm{J}, \mathrm{K}$ and $\mathrm{U}$ in Figure 1 [Miura et al. 2000]. The earthquake hypocenters were concentrated in a zone that trended E-W.
Tanaka et al. [2002] reported a region of anomalously high seismic velocity beneath the Onawashiro crater (Figure 1), which was attributed to a body of solidified magma. A similar model was proposed by Aizawa et al. [2009] based on a magnetotelluric survey.

\section{Sampling and analysis of gas and water}

Most of the fumarolic gases at sites $\mathrm{H}, \mathrm{J}, \mathrm{K}, \mathrm{U}$ and $\mathrm{A}$ (Figure 1) were sampled following the method proposed by Ozawa [1968], using a glass syringe in which $20 \mathrm{ml}$ of $5 \mathrm{M}$ $\mathrm{KOH}$ solution was filled, to absorb acidic gases. This method results in only a small amount of air contamination in the syringe. The $\mathrm{KOH}$ solution obtained was subjected to wet chemical analysis, according to Ozawa [1968]. The gas phase collected in the syringe, which included the "residual» composition of the gas (e.g., $\mathrm{N}_{2}, \mathrm{O}_{2}, \mathrm{H}_{2}, \mathrm{CH}_{4}, \mathrm{Ar}$, He and $\mathrm{Ne}$ ), was analyzed using two gas chromatographs (GCs) with $\mathrm{Ar}$ and $\mathrm{O}_{2}$ as the carrier gases, through which the components other than $\mathrm{Ar}$ and $\mathrm{O}_{2}$ were analyzed. The GC data were then combined to yield the complete composition of the residual gas. Fumarolic gases at site J were sampled in 2004 and 2006 for He isotope analysis, using an evacuated glass bottle [Giggenbach and Goguel 1989] that included $20 \mathrm{ml} 5 \mathrm{M} \mathrm{KOH}$, to prevent air contamination. At site J, hot spring water was also sampled in 1998 and 1999. Two fumaroles at site J were selected for repeated sampling. One series of samples (Table 1, 


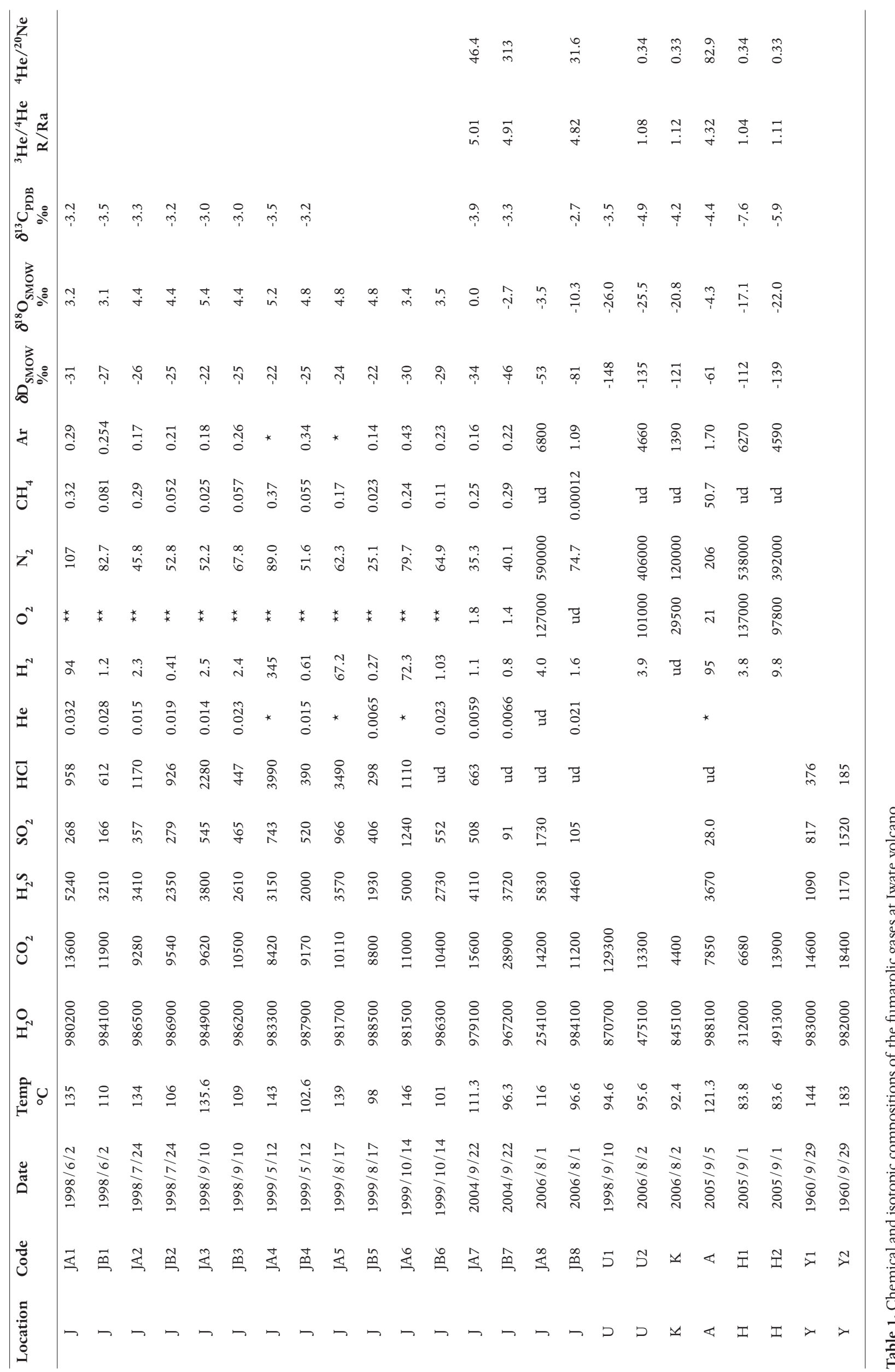

军

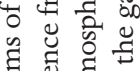

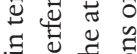

这. :

पू

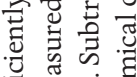

要

흘

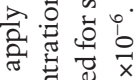

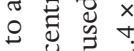

窟

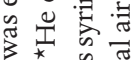

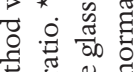

它

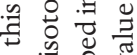

(⿸丆口广

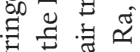

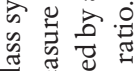

so

, 8 .

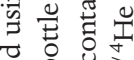

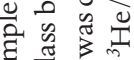

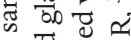

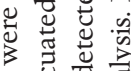

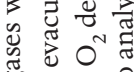

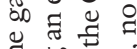

$\Rightarrow$.

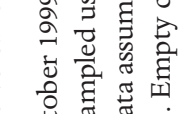

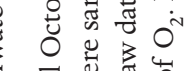

E

5) 虽脶 5 च 摛

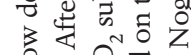

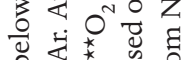

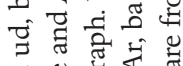

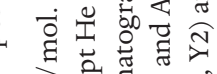
훙 힘 $z^{N}$

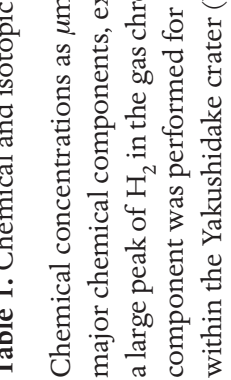


JA1-JA8) was collected at the fumarole with the highest outlet temperature. A second series (Table 1, JB1-JB8) was sampled at a fumarole located $32 \mathrm{~m}$ from the first. In addition, hot spring waters were sampled at site $J$ for analysis of their anionic compositions by ion chromatography.

To measure the $\delta \mathrm{D}$ values of $\mathrm{H}_{2} \mathrm{O}$ in the fumarolic gases, we sampled the gas condensates. Part of the condensates was converted to $\mathrm{H}_{2}$ gas with metallic $\mathrm{Zn}$ [Coleman et al. 1982] for analysis using mass spectrometry (Finnigan MAT 252). The same procedure was used for measuring the $\delta \mathrm{D}$ value of $\mathrm{H}_{2} \mathrm{O}$ in hot spring water. The $\delta^{18} \mathrm{O}$ values of $\mathrm{H}_{2} \mathrm{O}$ in the condensate and water sample were measured using the conventional $\mathrm{CO}_{2}-\mathrm{H}_{2} \mathrm{O}$ equilibration method [Epstein and Mayeda 1953], using mass spectrometry. To measure the $\delta^{13} \mathrm{C}$ value of $\mathrm{CO}_{2}$ in the fumarolic gases, the $\mathrm{CO}_{2}$ in the gases was fixed as a $\mathrm{BaCO}_{3}$ precipitate at the sampling site [Kusakabe 2001]. The precipitate was converted to $\mathrm{CO}_{2}$ in the laboratory for analysis by mass spectrometry. The analytical errors were $1.0 \%, 0.1 \%$, and $0.1 \%$ or for $\delta \mathrm{D}, \delta^{18} \mathrm{O}$ and $\delta^{13} \mathrm{C}$, respectively. The gas collected in the headspace of the evacuated bottle was analyzed noble mass spectrometer (MM5400), to obtain the rare gas composition and ${ }^{3} \mathrm{He} /{ }^{4} \mathrm{He}$ ratio. The analytical error of the ${ }^{3} \mathrm{He} /{ }^{4} \mathrm{He}$ measurements was less than $\pm 0.1 \mathrm{Ra}$.

Analyses of chemical and stable isotopes were performed at the Kusatsu-Shirane Volcano Observatory at Gunma Prefecture, Japan, and those of He isotopes were performed at the Geological Survey of Japan at Tsukuba city, Japan.

\section{Results}

\subsection{Major components of fumarolic gases}

Tables 1 and 2 list the chemical and isotopic data for the fumarolic gases and hot spring waters, respectively. The major components of the fumarolic gases are $\mathrm{H}_{2} \mathrm{O}, \mathrm{CO}_{2}, \mathrm{H}_{2} \mathrm{~S}, \mathrm{SO}_{2}$ and $\mathrm{HCl}$. Figure 2 shows a ternary diagram of the $\mathrm{H}_{2} \mathrm{O}, \mathrm{CO}_{2}$ and $\mathrm{S}$ concentrations in the fumarolic gases (where $\mathrm{S}=\mathrm{H}_{2} \mathrm{~S}+$ $+\mathrm{SO}_{2}$ ). Except for the samples JB7 and JA8, the gases at site J are clustered in the center of the diagram, along with the sole sample from site $\mathrm{A}$. The gases at sites $\mathrm{U}, \mathrm{K}$ and $\mathrm{H}$ are depleted in $\mathrm{S}$; as such, they lie along the right-hand edge of the ternary diagram in Figure 2. The $\mathrm{CO}_{2} / \mathrm{H}_{2} \mathrm{O}$ ratios of samples from sites $\mathrm{H}$ and $\mathrm{U}$ are distinctly (although only slightly) higher than those of the cluster (except for sample U1). Sample U1 is strongly depleted in $\mathrm{H}_{2} \mathrm{O}$, whereas the sample from site $\mathrm{H}$ is enriched in $\mathrm{H}_{2} \mathrm{O}$. Gases at Yakushidake crater, as sampled in 1960, were enriched in S, similar to the composition of gases at site $\mathrm{J}$.

\subsection{Temporal variations in the compositions of the fumarolic gases at site $J$}

Figure 3 shows the temporal variations in the chemical compositions and isotope ratios of the gases from site $\mathrm{J}$.
The $\mathrm{CO}_{2}$ and $\mathrm{H}_{2} \mathrm{~S}$ concentrations were relatively low in 1999, and they showed slight increases in 2004 and 2006. The $\mathrm{SO}_{2}$ concentrations in the JA samples increased from June 1988 to October 1999, followed by a decrease in 2004 and an increase in 2006. Except for 2006, the temporal variations observed for the JB samples are similar to those for the JA samples. The $\mathrm{HCl}$ concentrations in the JA samples show an increase from June 1998 to May 1999, followed by a decrease. The $\mathrm{HCl}$ concentrations in the JB samples were relatively high in July 1998, but decreased gradually thereafter. The $\mathrm{H}_{2}$ concentrations in the JA samples were high in May 1999, moderate in late 1999, and low in 2004 and 2006. The $\mathrm{CH}_{4}$ concentrations in the JA and JB samples show no clear temporal trends. There is no correlation between the values of the JA and JB series. The $\delta \mathrm{D}$ and $\delta^{18} \mathrm{O}$ values were high until August 1999, but decreased thereafter.

\begin{tabular}{|c|c|c|c|c|c|c|c|}
\hline Code & Date & $\begin{array}{c}\text { Temp } \\
{ }^{\circ} \mathrm{C}\end{array}$ & $\mathrm{pH}$ & $\begin{array}{c}\delta \mathrm{D}_{\text {SMOW }} \\
\% \text { \%o }\end{array}$ & $\begin{array}{c}\delta^{18} \mathrm{O}_{\text {SMOW }} \\
\% \text { o }\end{array}$ & $\begin{array}{c}\mathrm{Cl}^{-} \\
\mathrm{mg} / \text { liter }\end{array}$ & $\begin{array}{c}\mathrm{SO}_{4}^{2-} \\
\mathrm{mg} / \mathrm{liter}\end{array}$ \\
\hline W1 & $1998 / 7 / 24$ & 75.7 & 2.4 & -69 & -10.4 & 290 & 825 \\
\hline W2 & $1998 / 7 / 24$ & 30.6 & 2.5 & -73 & -11.5 & 26 & 1820 \\
\hline W3 & $1998 / 7 / 24$ & 70.1 & 1.0 & -21 & 4.9 & 9300 & 4050 \\
\hline W4 & $1998 / 7 / 24$ & 95.3 & 2.1 & -64 & -8.9 & 711 & 2520 \\
\hline W5 & $1998 / 9 / 10$ & 94.8 & 1.2 & -31 & 0.2 & 4309 & 2230 \\
\hline W6 & $1998 / 9 / 10$ & 78.2 & 2.3 & -68 & -9.8 & 472 & 800 \\
\hline W7 & $1998 / 9 / 10$ & 96.7 & 2.0 & -53 & -6.2 & 489 & 2211 \\
\hline W8 & $1998 / 9 / 10$ & 90.9 & 2.1 & -64 & -9.3 & 442 & 730 \\
\hline W9 & $1999 / 5 / 12$ & 74.2 & 1.9 & -73 & -10.9 & 14 & 1700 \\
\hline W10 & $1999 / 5 / 12$ & 94.4 & 2.0 & -60 & -7.5 & 160 & 997 \\
\hline W11 & $1999 / 5 / 12$ & 95.1 & 0.9 & -18 & 4.8 & 8330 & 4790 \\
\hline
\end{tabular}

Table 2. Chemical and isotopic compositions of the hot spring waters sampled at site J.

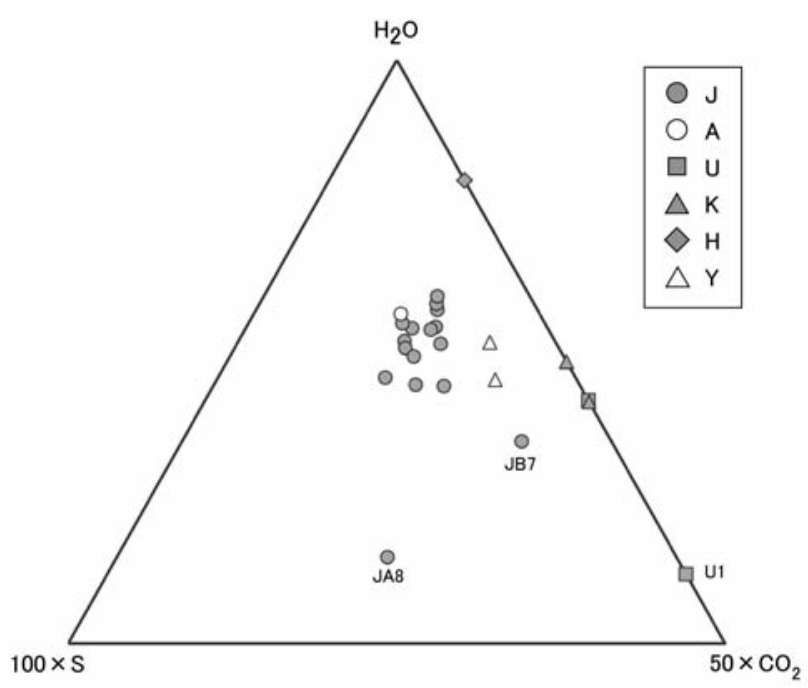

Figure 2. $\mathrm{H}_{2} \mathrm{O}-\mathrm{CO}_{2}-\mathrm{S}$ ternary diagram $\left(\mathrm{S}=\mathrm{H}_{2} \mathrm{~S}+\mathrm{SO}_{2}\right)$ showing the compositions of the fumarolic gases (molar basis). 

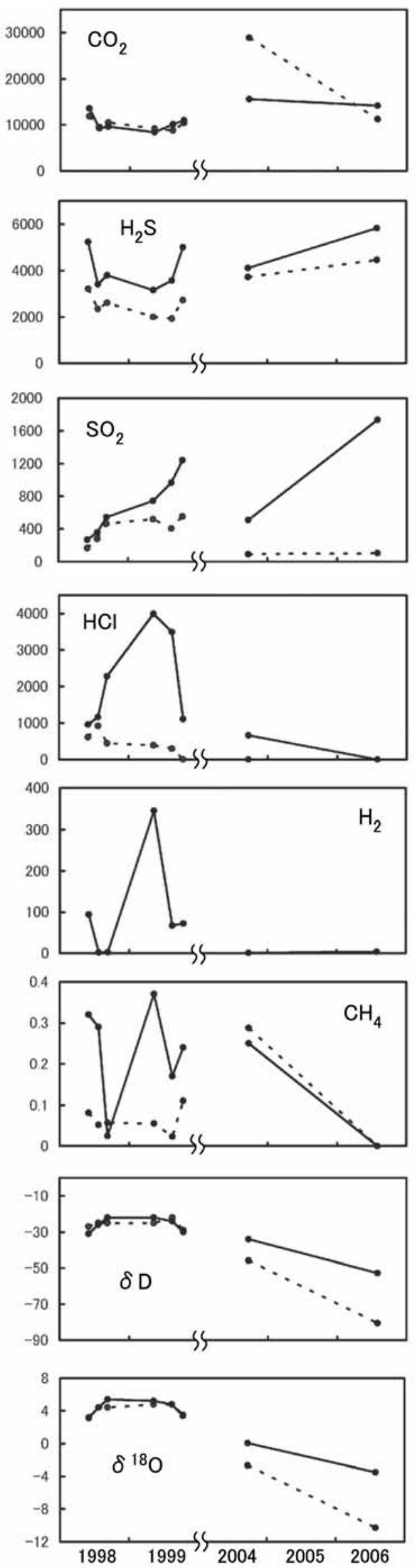

Figure 3. Temporal variations in the compositions $(\mu \mathrm{mol} / \mathrm{mol})$ and isotope ratios (\%o relative to SMOW) of the water in the fumarolic gases from site $\mathrm{J}$ (as indicated). Solid and dotted lines, JA and JB series, respectively.

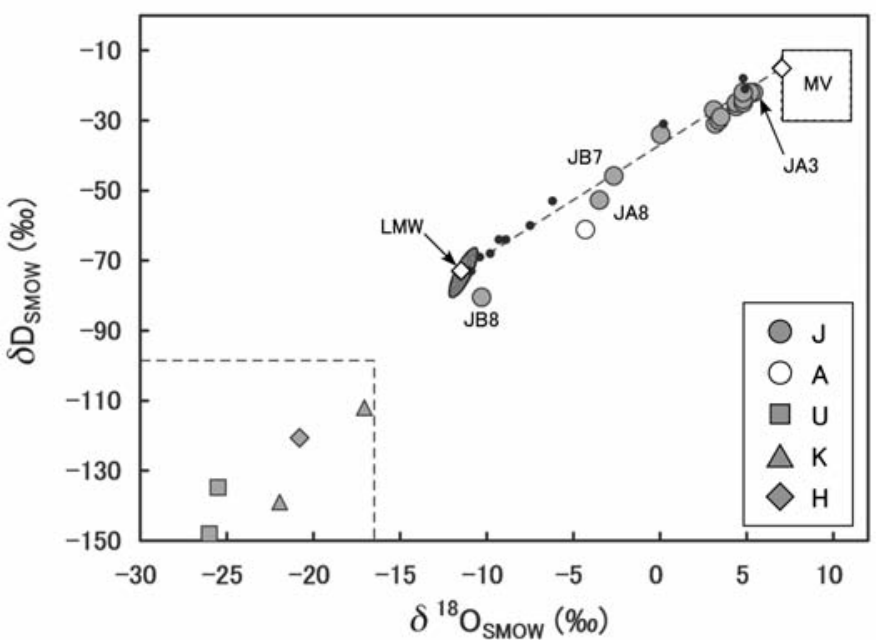

Figure 4. The $\delta \mathrm{D}$ and $\delta^{18} \mathrm{O}$ values of water in the fumarolic gases and hot spring waters. Square, upper right, general range of the values for the typical MV of an andesitic volcano above a subduction zone. Elliptical region, local meteoric water (LMW) at the summit area of Iwate volcano [Kazahaya et al. 2000]. Small filled dots, isotope ratios of the hot spring water. Dashed horizontal and vertical lines, bottom left, $\delta \mathrm{D}$ and $\delta^{18} \mathrm{O}$, respectively, of the water vapor equilibrated with the LMW at $100{ }^{\circ} \mathrm{C}$.

\subsection{Isotope ratios of $\mathrm{H}_{2} \mathrm{O}$ in the gases and water}

In 1999 , the $\delta \mathrm{D}$ and $\delta^{18} \mathrm{O}$ values of $\mathrm{H}_{2} \mathrm{O}$ in the gases at site J were high, similar to those of magmatic water (typical of andesitic volcanoes) [Taran et al. 1989], as shown in Figure 4 . The gases with high isotope ratios contained high concentrations of $\mathrm{HCl}$ (e.g., JA4). In Figure 4, the gases from site $\mathrm{J}$ are distributed along the line connecting the general magmatic water (Figure 4, square at top right) and local meteoric water, as reported by Kazahaya et al. [2000], who analyzed seven water samples from altitudes of $1,300 \mathrm{~m}$ to $1,800 \mathrm{~m}$ on the Iwate volcano. The average $\delta \mathrm{D}$ and $\delta^{18} \mathrm{O}$ values of the seven samples were $-73 \%$ and $-11.5 \%$, respectively.

Some of the hot spring waters (Table 2, W3 and W11) sampled at site J yielded high isotope ratios, close to those of magmatic water. The concentration of $\mathrm{Cl}^{-}$in samples $\mathrm{W} 3$ and W11 was $9,300 \mathrm{mg} / \mathrm{L}$ and $8,330 \mathrm{mg} / \mathrm{L}$, respectively, which is equivalent to $4,720 \mathrm{mmol} / \mathrm{mol}$ and $4,230 \mathrm{mmol} / \mathrm{mol}$ as the $\mathrm{Cl} / \mathrm{H}_{2} \mathrm{O}$ molar ratio (similar to the $\mathrm{HCl} / \mathrm{H}_{2} \mathrm{O}$ molar ratio for sample JA4: 4,060 $\mathrm{mmol} / \mathrm{mol}$ ). In Figure 4, the isotope ratios of the hot spring waters are also distributed along the line connecting the magmatic vapor (MV) and the local meteoric water (LMW).

The $\delta \mathrm{D}$ and $\delta^{18} \mathrm{O}$ values of $\mathrm{H}_{2} \mathrm{O}$ in the gases from sites $\mathrm{U}, \mathrm{K}$ and $\mathrm{H}$ are much lower than those of the LMW, and the isotope ratios of the gases are much lower than those of the vapors equilibrated with the LMW at $100{ }^{\circ} \mathrm{C}$.

\subsection{Residual gas composition}

Figure 5 shows the compositional data for the fumarolic gases at site J plotted on a $\mathrm{N}_{2}-\mathrm{He}$-Ar ternary diagram. The data 


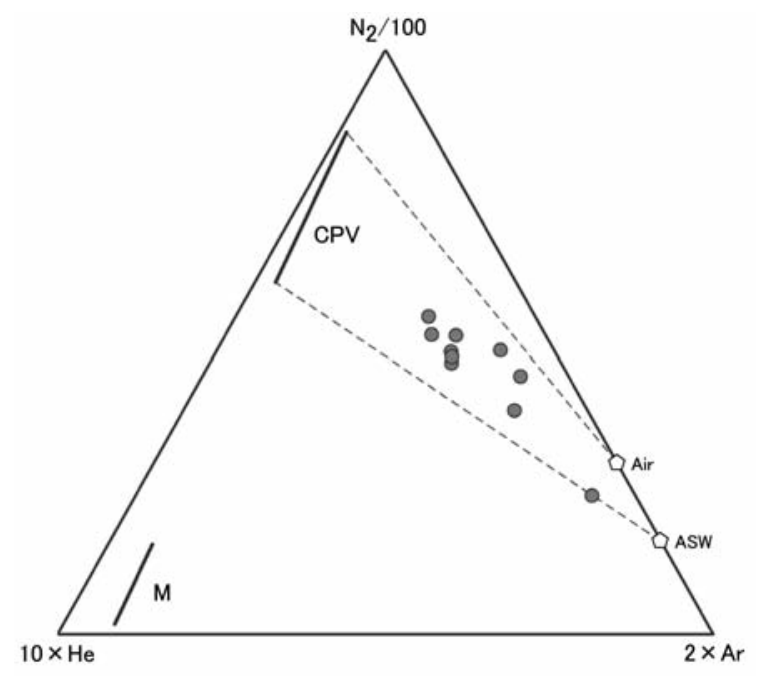

Figure 5. $\mathrm{N}_{2}$-He-Ar ternary diagram showing the compositions of the fumarolic gases at site J (molar basis). Circum-Pacific volcanoes (CPV) and $\mathrm{M}$, end members typical of the CPV gases and gases originating in the mantle, respectively. ASW, composition of the water saturated with air. The data are plotted from Table 1

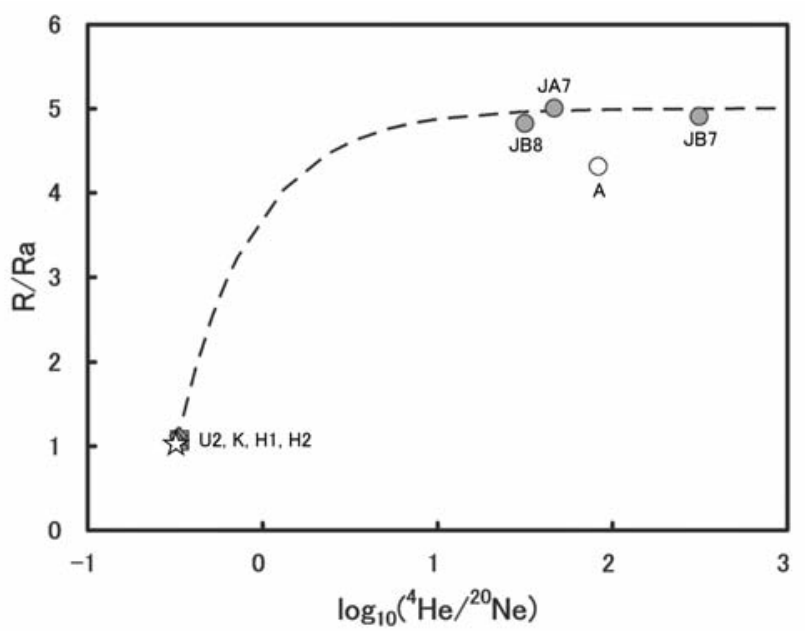

Figure 6. ${ }^{3} \mathrm{He} /{ }^{4} \mathrm{He}$ versus ${ }^{4} \mathrm{He} /{ }^{20} \mathrm{Ne}$ ratios of the fumarolic gases. $\mathrm{R}$ and $\mathrm{Ra},{ }^{3} \mathrm{He} /{ }^{4} \mathrm{He}$ ratios of fumarolic gas and air $\left(1.4 \times 10^{-6}\right)$, respectively. Dashed curve, mixing line between air and an end member with an $\mathrm{R} / \mathrm{Ra}$ of 5 and a ${ }^{4} \mathrm{He} /{ }^{20} \mathrm{Ne}$ of 1000 .

points are distributed in the region of mixing between the end member with a high $\mathrm{N}_{2} /$ Ar ratio and the atmospheric end members. The end member with a high $\mathrm{N}_{2} /$ Ar ratio can be represented by the gas of the Circum-Pacific volcanoes (Figure 5, CPVs) [Giggenbach 1997]. The ${ }^{3} \mathrm{He} /{ }^{4} \mathrm{He}$ ratios in the fumarolic gases are plotted in Figure 6 (JA7, JB7, JB8 and A), where the ${ }^{3} \mathrm{He} /{ }^{4} \mathrm{He}$ ratio is normalized by the ratio of air $(=\mathrm{R} / \mathrm{Ra})$. The $\mathrm{R} / \mathrm{Ra}$ and ${ }^{4} \mathrm{He} /{ }^{20} \mathrm{Ne}$ ratios of $\mathrm{U}, \mathrm{K}$ and $\mathrm{H}$ are almost identical to the atmospheric values. The data points for JA7, JB7 and JB8 plot along the mixing line, the end members of which are air and a component with a high ${ }^{4} \mathrm{He} /{ }^{20} \mathrm{Ne}$ ratio. The $\mathrm{R} / \mathrm{Ra}$ ratio of the end member is estimated to have a value of 5 , which is slightly lower than the value of 6 reported for He in magmatic gas from the Japanese islands [Poreda and Craig 1989]. Fumarolic gas from site A lies beneath the mixing line in Figure 6, suggesting an additional contribution of a ${ }^{4} \mathrm{He}$-enriched component that probably originated in the crustal rock.

Figure 7 shows the relationships between the $\delta^{13} \mathrm{C}$ value of $\mathrm{CO}_{2}$ and the $\mathrm{CO}_{2} /{ }^{3} \mathrm{He}$ molar ratios, indicating that the origin of the $\mathrm{CO}_{2}$ is the fumarolic gases [e.g., Marty et al. 1989, Sano and Marty 1995]. $\mathrm{CO}_{2}$ in volcanic gases can originate from the upper mantle (e.g., volatiles in the midoceanic ridge basalt; Figure 7, MORB), the sea-floor sediment (Figure 7, S), or limestone (Figure 7, L). The $\mathrm{CO}_{2}$ in fumarolic gases at site $\mathrm{J}$ originated mainly from limestone, with a minor contribution of MORB-type $\mathrm{CO}_{2}$.

\section{Discussion}

\subsection{Apparent equilibrium temperature}

The apparent equilibrium temperature (AET) is an index of volcanic activity [Giggenbach 1987], and it can be regarded as the quenched temperature of volcanic gas. As $\mathrm{H}_{2}$ gas is the most reactive component in fumarolic gases, and because $\mathrm{H}_{2}$ included in the following reaction has a stoichiometric coefficient of 3 , the AET for the reaction:

$$
\mathrm{SO}_{2}+3 \mathrm{H}_{3}=\mathrm{H}_{2} \mathrm{~S}+2 \mathrm{H}_{2} \mathrm{O}
$$

is expected to be a proxy of gas temperature in the conduit connecting the gas source and the outlet of the fumarole. The temperature of the gas conduit is initially high, as it is similar to the temperature of the magma at depth, but it decreases with the ascent of the gas. At high temperatures, the equilibrium of Equation (1) shifts to the left side of the reaction. During the ascent of the gas within the conduit, the temperature decreases, resulting in a shift in the

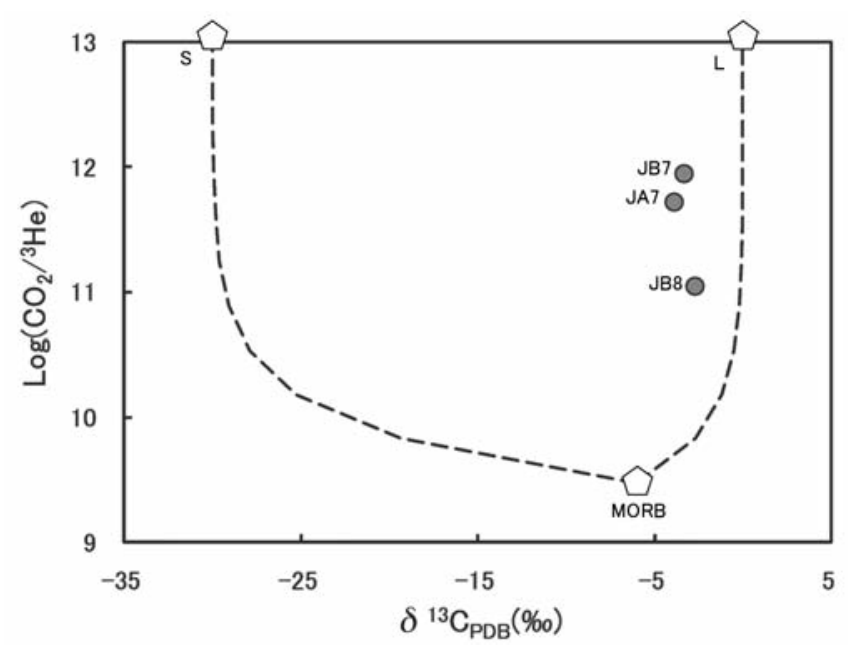

Figure 7. $\mathrm{CO}_{2} /{ }^{3} \mathrm{He}$ ratios and $\delta^{13} \mathrm{C}$ values of $\mathrm{CO}_{2}$ within the fumarolic gases from site J. L, S, end members typical of oceanic sediment $(S)$ and oceanic limestone $(\mathrm{L})$, respectively. Dashed curves, mixing between $S$ and MORB and between $L$ and MORB. 


\begin{tabular}{ccc}
\hline Code & $\begin{array}{c}\text { Temp (outlet) } \\
{ }^{\circ} \mathbf{C}\end{array}$ & $\begin{array}{c}\text { AET } \\
{ }^{\circ} \mathbf{C}\end{array}$ \\
\hline JA1 & 135 & 464 \\
JB1 & 110 & 229 \\
JA2 & 134 & 263 \\
JB2 & 106 & 201 \\
JA3 & 136 & 271 \\
JB3 & 109 & 273 \\
JA4 & 143 & 642 \\
JB4 & 103 & 223 \\
JA5 & 139 & 482 \\
JB5 & 98 & 193 \\
JA6 & 146 & 486 \\
JB6 & 101 & 240 \\
JA7 & 111 & 236 \\
JB7 & 96 & 206 \\
JA8 & 116 & 379 \\
JB8 & 97 & 230 \\
\hline
\end{tabular}

Table 3. Apparent equilibrium temperatures (AETs) for the chemical compositions of JA and JB.

equilibrium of Equation (1) to the right side. However, the reaction takes some time to reach completion, and if the gas ascends rapidly, the shift in the reaction is incomplete, resulting in a high AET. In this case, the increase in the AET is interpreted as reflecting a rapid ascent of the gas.

AET was calculated for the composition of the JA and JB series, as follows:

$$
\operatorname{AET}\left({ }^{\circ} \mathrm{C}\right)=\frac{8924}{\mathrm{LQ}-1.242}-273.15
$$

where LQ is the logarithm of the quotient,

$$
\mathrm{LQ}=\log \left\{\left(\frac{\mathrm{C}_{\mathrm{H}_{2} \mathrm{~S}}}{\mathrm{C}_{\mathrm{H}_{2} \mathrm{O}}}\right)\left(\frac{\mathrm{C}_{\mathrm{SO}_{2}}}{\mathrm{C}_{\mathrm{H}_{2} \mathrm{O}}}\right)^{-1}\left(\frac{\mathrm{C}_{\mathrm{H}_{2}}}{\mathrm{C}_{\mathrm{H}_{2} \mathrm{O}}}\right)^{-3}\right\}
$$

where $C i$ is the concentration of gas species $i$. Equation (2) was obtained from the temperature dependence of the standard equilibrium constant of formation, as compiled by Giggenbach [1987]. The total pressure of gas is assumed to be the saturated pressure of water vapor at the calculated AET (see Table 3).

Figure 8 shows the temporal variations in the AET and the outlet temperature of the gas. The AET of the JA series showed a significant increase in 1999, over 1998. The outlet temperature of JA increased slightly in 1999 compared with 1998. Miura et al. [2000] reported that the seismic activity beneath Onawashiro crater was high until September 1998, and decreased thereafter. The increase in AET for the JA series lags behind the period of active seismicity. The AET values for the JB series show no clear temporal trends. The short distance between fumaroles JA and JB indicates that the processes governing the temporal variations in the AET of JA was active at shallow depths.

\subsection{Magmatic vapor at site $J$}

The $\mathrm{H}_{2} \mathrm{O}$ isotope ratios of the JA and JB series fall along a line connecting the point for the LMW and the water vapor with a magmatic origin (Figure $4, \mathrm{MV}$ ). The $\delta \mathrm{D}$ and $\delta^{18} \mathrm{O}$ values of the MV are similar to those for the JA and JB series; consequently, the line connecting the LMW and the MV passes through the cluster of data points near the MV. The $\delta^{18} \mathrm{O}$ value of the MV was tentatively assumed to be $+7 \%$ o relative to the SMOW, which is in the range of typical values for andesitic volcanoes above a subduction zone [Giggenbach 1992]. The $\delta^{18} \mathrm{O}$ value of the $\mathrm{MV}$ is limited to less than $+8.5 \%$, because the upper limit for $\delta \mathrm{D}$ of water in andesitic magma is $-10 \%$ [Giggenbach 1992]. The $\delta^{18} \mathrm{O}$ value of JA3 is $+5.4 \%$, close to that of the MV.

JA3 contains high concentrations of $\mathrm{HCl}$. If liquid water encounters a gas similar to that of sample JA3, most of the $\mathrm{HCl}$ in the gas would be absorbed by the liquid phase, making the vapor phase depleted in HCl. During September 1998 at Iwate volcano, there was relatively little contamination by water, and consequently there was a higher $\mathrm{HCl}$ content in the gas phase. After contamination, no liquid phase remains because it absorbs $\mathrm{HCl}$ in the gas phase. For the above case, the temperature of the MV was estimated according to the following equations:

$$
\delta_{\mathrm{F}}=\delta_{\mathrm{MV}} f+\delta_{\mathrm{LMW}}(1-f)
$$

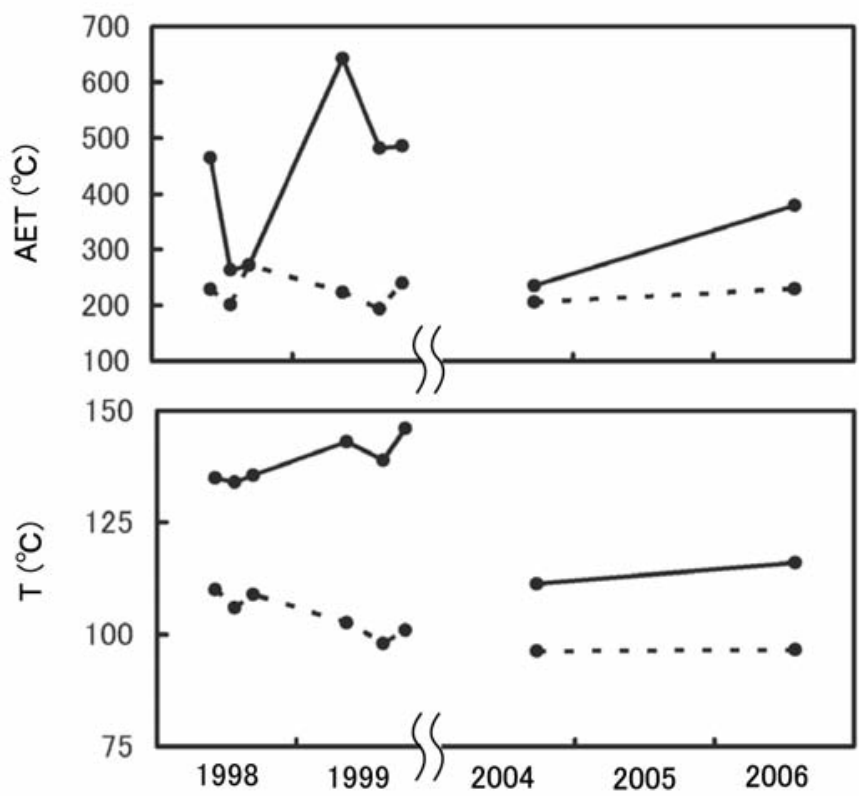

Figure 8. Temporal variations in the apparent equilibrium temperature (AET) calculated for the chemical compositions of the JA (solid lines) and JB (dashed lines) series (upper), and for the outlet temperatures of the gases (lower). 


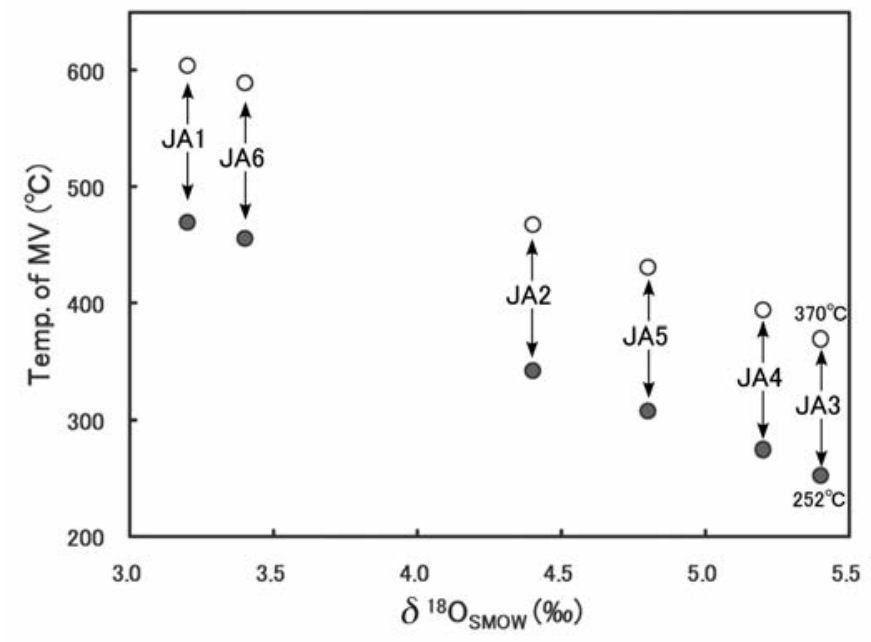

Figure 9. Estimated temperatures of the MV. Filled, open circles, estimates assuming $\delta^{18} \mathrm{O}$ for magmatic vapor of $+7 \%$ and $+8.5 \%$, respectively.

$$
\mathrm{H}_{\mathrm{F}}=\mathrm{H}_{\mathrm{MV}} f+\mathrm{H}_{\mathrm{LMW}}(1-f)
$$

where $\delta$ is the $\delta^{18} \mathrm{O}$ value of the gas and the water; the subscripts F, MV and LMW indicate the fumarolic gas, MV and LMW, respectively; $f$ is the molar fraction of $\mathrm{H}_{2} \mathrm{O}$ derived from the $\mathrm{MV} ; \mathrm{H}$ is the enthalpy of gas and water; $\delta_{\mathrm{MV}}$ is assumed to be $+7 \%$ or $+8.5 \%$; $\delta_{\mathrm{LMW}}$ is assumed to be $-11.5 \%$; and $\delta_{\mathrm{F}}$ gives $f$ according to Equation (4). The $f$ obtained is substituted into Equation (5). HF was assumed to be the enthalpy of saturated $\mathrm{H}_{2} \mathrm{O}$ vapor at the temperature of the fumarolic gas. $\mathrm{H}_{\mathrm{LMW}}$ was $42 \mathrm{~kJ} / \mathrm{kg}$, which is the enthalpy of liquid water at $10^{\circ} \mathrm{C}$. Solving Equation (5), HMV can be obtained. The temperature of the MV was estimated assuming that the MV is a super-heated water vapor under a pressure of 1 bar (the gas pressure beneath the surface is expected to exceed 1 bar). The temperature of the MV obtained is the potential temperature at the surface when the volcanic gas expands, with the enthalpy of water vapor kept constant. The temperature of the MV depends on $\delta_{\mathrm{F}}$ and on the temperature of the fumarolic gas, although the effects of temperature are small relative to those of $\delta_{\mathrm{F}}$.

The calculated temperature is shown in Figure 9. The temperature is lowest for JA3, for which the $\delta_{\mathrm{F}}$ value is highest. As discussed below, the JA series is affected by the partial condensation of $\mathrm{H}_{2} \mathrm{O}$ vapor, resulting in reduced $\delta_{\mathrm{F}}$ values. The calculated temperature of the $\mathrm{MV}$ at JA3 is $252{ }^{\circ} \mathrm{C}$ and $370{ }^{\circ} \mathrm{C}$ for the $\delta_{\mathrm{MV}}$ values of $+7 \%$ ond $+8.5 \%$, respectively. These temperatures are much lower than the general temperatures of degassing magma. It is therefore necessary to invoke a cooling process during the ascent of the MV from the source to the surface.

\subsection{Correlation between $\delta^{18} \mathrm{O}$ values of $\mathrm{H}_{2} \mathrm{O}$ and $\mathrm{CO}_{2} / \mathrm{H}_{2} \mathrm{O}$}

The correlation between the chemical and isotopic compositions of fumarolic gases can be explained by a simple model [Ohwada et al. 2003, Ohba 2007, Ohba et al. $2010]$ in the case of the Tatun volcanoes (Taiwan), the IzuOshima volcano (Japan) and the Kusatsu-Shirane volcano (Japan), for which the fumarolic gas is the vapor phase that is generated between high-temperature magmatic gas and low-temperature groundwater after mixing. As shown in the following equations, a simple mixing between fluids is the basis of the calculations of the composition of the vapor phase, assuming the conservation of total enthalpy with the amount of substance, and the partitioning equilibrium between the vapor and liquid phases.

$$
\begin{gathered}
\mathrm{H}_{\mathrm{Mv}} f+\mathrm{H}_{\mathrm{LMW}}(1-f)=\mathrm{H}_{\mathrm{Ps}} g+\mathrm{H}_{\mathrm{PW}}(1-g) \\
\delta_{\mathrm{Mv}} f+\delta_{\mathrm{LMW}}(1-f)=\delta_{\mathrm{Ps}} g+\delta_{\mathrm{PW}}(1-g) \\
\mathrm{C}_{\mathrm{Mv}} f+\mathrm{C}_{\mathrm{LMW}}(1-f)=\mathrm{C}_{\mathrm{Ps}} g+\mathrm{C}_{\mathrm{PW}}(1-g) \\
\alpha=\frac{\delta_{\mathrm{PW}}+1000}{\delta_{\mathrm{PS}}+1000} \\
\beta_{{\mathrm{Cl} \mathrm{lor} \mathrm{CO}_{2}}_{2}}=\frac{\mathrm{C}_{\mathrm{PS}}}{\mathrm{C}_{\mathrm{PW}}}
\end{gathered}
$$

where $\mathrm{C}$ is the molar concentration of $\mathrm{CO}_{2}$ or $\mathrm{HCl}$; the subscripts PS and PW indicate the vapor phases (primary steam; PS) and the co-existing liquid phase (primary thermal water; PW), respectively, generated from the mixing of the MV and the LMW; and $\mathrm{f}$ and $\mathrm{g}$ denote the mixing fraction of the MV and the generating fraction of the PS, respectively. In general, $g$ is not equal to $f$.

Equations (6), (7) and (8) describe the conservation of enthalpy, the isotope ratio, and the chemical composition $\left(\mathrm{CO}_{2} / \mathrm{H}_{2} \mathrm{O}\right.$ or $\mathrm{Cl} / \mathrm{H}_{2} \mathrm{O}$ ratio) for the generation of the PS and the PW, respectively. Equations (9) and (10) describe the equilibrium between PS and PW in terms of stable isotopes, $\mathrm{CO}_{2}$, or the distribution of $\mathrm{HCl} \alpha$ is the isotope fractionation factor of $\mathrm{H}_{2} \mathrm{O}$ [Horita and Wesolowski 1994], and $\beta$ is the distribution coefficient of $\mathrm{CO}_{2}$ [Giggenbach 1980]. The partitioning of $\mathrm{HCl}$ between the vapor phase and the liquid phase is complicated relative to that of $\mathrm{CO}_{2}$, because $\mathrm{HCl}$ is ionized into $\mathrm{H}^{+}$and $\mathrm{Cl}^{-}$in the liquid phase.

The calculated composition of PS is shown in Figure 10, along with data points for the fumarolic gases. The $\mathrm{X}$ axis in Figure 10 is the scaled fraction $(\mathrm{ScF})$ of $\mathrm{CO}_{2}$ in the $\mathrm{CO}_{2}-\mathrm{H}_{2} \mathrm{O}$ binary system, defined by:

$$
\mathrm{ScF}\left(\mathrm{CO}_{2}\right)=\frac{100 \mathrm{C}_{\mathrm{CO}_{2}}}{100 \mathrm{C}_{\mathrm{CO}_{2}}+\mathrm{C}_{\mathrm{H}_{2} \mathrm{O}}} .
$$

The $\mathrm{ScF}$ is convenient in terms of plotting a wide range of $\mathrm{CO}_{2} / \mathrm{H}_{2} \mathrm{O}$ ratios on a single calibration axis. Given the degree of freedom in $\mathrm{f}$, the composition of PS is expressed as a curve. Smaller values of $f$ give lower $\delta^{18} \mathrm{O}$ values on the PS curve. The PS curve originates from the mixing curve 
between the MV and the LMW, and its location depends on the enthalpy of MV. In Figure 10, the enthalpy of MV was assumed to be equivalent to that of vapor heated to $400{ }^{\circ} \mathrm{C}$ at 1 bar. In constructing the PS curve, the $\mathrm{CO}_{2} / \mathrm{H}_{2} \mathrm{O}$ ratio of the MV was assumed to be 0.008 , which was chosen to explain the composition of the gas at site A. The correlation between $\delta^{18} \mathrm{O}$ and $\mathrm{CO}_{2} / \mathrm{H}_{2} \mathrm{O}$ in gases at site $\mathrm{J}$ is not compatible with the composition of PS. As shown above, the gas at site $\mathrm{J}$ with a high $\delta^{18} \mathrm{O}$ value could be a simple mixture of the MV and the LMW. The generation of a liquid phase is unlikely. because of the high $\mathrm{HCl}$ concentration in the gas at site $\mathrm{J}$.

Figure 10 shows a wide range of $\mathrm{CO}_{2} / \mathrm{H}_{2} \mathrm{O}$ ratios. Gases with a high $\mathrm{CO}_{2} / \mathrm{H}_{2} \mathrm{O}$ ratio have a lower $\delta^{18} \mathrm{O}$ value, which can be explained if the gas undergoes partial condensation of the water vapor, modeled by the Rayleigh process. The composition of the gas phase after the partial condensation of the water vapor is expressed as follows:

$$
\begin{gathered}
\delta=\left(\delta_{i}+1000\right) \mathrm{F}^{(\alpha-1)}-1000 \\
r=r_{i} \mathrm{~F}^{\left(\frac{1}{\beta}-1\right)}
\end{gathered}
$$

where $\mathrm{F}$ is the fraction of water vapor remaining after the condensation of the water vapor, $r$ is the $\mathrm{CO}_{2} / \mathrm{H}_{2} \mathrm{O}$ ratio of the gas phase (molar ratio), and the subscript $i$ represents the initial value of the gas before condensation. The gases from site $\mathrm{J}$ lie around the trend of condensation at $100{ }^{\circ} \mathrm{C}$ or $120{ }^{\circ} \mathrm{C}$, except JB8 (Figure 10).

The gas samples from $\mathrm{U}, \mathrm{K}$ and $\mathrm{H}$ lie far from the PS curve in Figure 10. The $\delta^{18} \mathrm{O}$ values of the gases are much

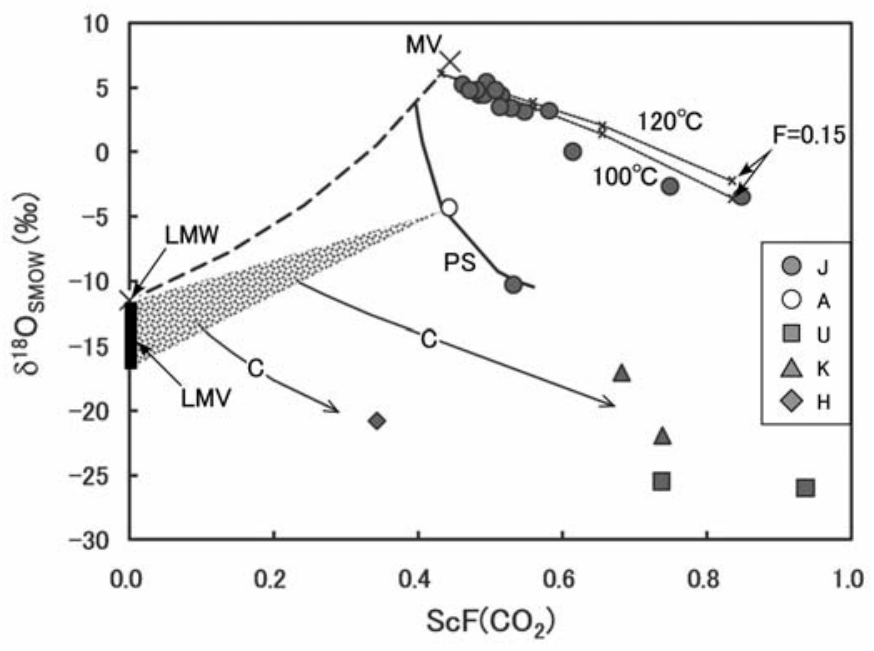

Figure 10. Correlation between the $\delta^{18} \mathrm{O}$ values of $\mathrm{H}_{2} \mathrm{O}$ and the $\mathrm{CO}_{2} / \mathrm{H}_{2} \mathrm{O}$ ratios in the fumarolic gases. Bold dashed curve, mixing line between the MV and the LMW. The LMV represents the vapor generated from the LMW at $100{ }^{\circ} \mathrm{C}$. Shaded region, mixture between the LMV and a gas similar to that from site A. Solid curve (labeled PS), composition of primary steam. Thin dashed curves and solid curves, trends of the partial condensation of the water vapor phase, for which $\mathrm{F}$ is the fraction of water vapor remaining after partial condensation.

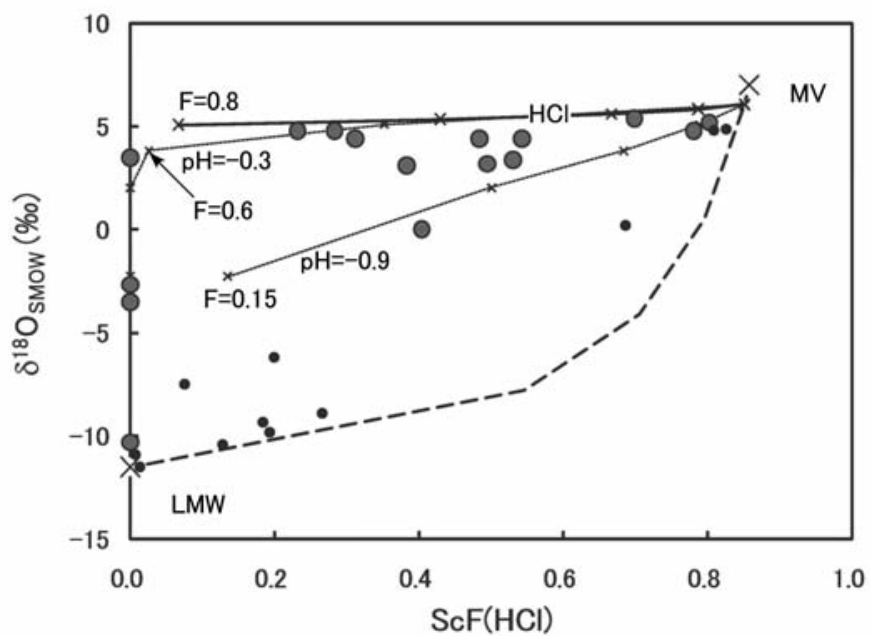

Figure 11. Correlation between the $\delta^{18} \mathrm{O}$ values of $\mathrm{H}_{2} \mathrm{O}$ and the $\mathrm{HCl} / \mathrm{H}_{2} \mathrm{O}$ ratios in the fumarolic gases from site J. Bold horizontal line, trend during the partial condensation of the vapor, where the condensed liquid contains $\mathrm{H}^{+}$and $\mathrm{Cl}^{-}$ions with a common molarity. Thin dashed curves, trends of partial condensation, for which the $\mathrm{pH}$ of the condensed liquid phase is fixed at -0.3 or -0.9 . Bold dashed curve, mixing line between the MV and the LMW.

lower than that of PS. Even if partial condensation is assumed for PS, the $\delta^{18} \mathrm{O}$ values would still be too high; however, the $\delta^{18} \mathrm{O}$ value can be reduced by introducing a vapor phase that originated from the LMW. If groundwater is heated in the shallow crust within a geothermal area, some of the water would be vaporized. The isotope ratio of the vapor generated (the local meteoric vapor; LMV) is shown on the Y-axis in Figure 10. Given the freedom of the fraction of vaporized water, the $\delta^{18} \mathrm{O}$ value of the LMV is expressed as a line. The addition of the LMV to a gas phase (e.g., the gas at $\mathrm{A}$ ) produces a gas phase with a low $\mathrm{CO}_{2} / \mathrm{H}_{2} \mathrm{O}$ ratio, as shown by the shaded region in Figure 10. If such a gas undergoes partial condensation, the composition of the remaining gas phase would approach the composition of the gas from sites $\mathrm{U}, \mathrm{K}$ and $\mathrm{H}$.

\subsection{Correlation between $\delta^{18} \mathrm{O}$ values of $\mathrm{H}_{2} \mathrm{O}$ and $\mathrm{HCl} / \mathrm{H}_{2} \mathrm{O}$}

The $\mathrm{HCl}$ concentrations in the vapor phase (after partial condensation) can also be calculated under the assumption of a Rayleigh process. Two different cases are assumed in terms of condensation. In the first case, the condensed liquid phase is a pure $\mathrm{HCl}$ solution. The concentration of $\mathrm{H}^{+}$in the condensed liquid is equal to that of the $\mathrm{Cl}^{-}$ions. In this case, the $\mathrm{HCl}$ concentration in the vapor phase is given by:

$$
m=\frac{1}{k}\left(1-\frac{1}{\sqrt{\mathrm{F}}}+\sqrt{\frac{\mathrm{Km}}{\mathrm{F}}}\right)^{2}
$$

where $m$ is the molarity of $\mathrm{HCl}$ in the vapor phase, and $\mathrm{K}$ is the partitioning factor of $\mathrm{HCl}$ between the vapor and liquid phases, as defined by: 


$$
\mathrm{K}=\frac{m}{m_{\mathrm{H}^{+}} m_{\mathrm{Cl}^{-}}}
$$

where $m_{\mathrm{H}^{+}}$and $m_{\mathrm{Cl}^{-}}$are the molarities of the $\mathrm{H}^{+}$and $\mathrm{Cl}^{-}$ions in the condensed liquid phase, respectively. The temperature dependence of K was given by Simonson and Palmer (1993). The temperature during condensation was assumed to be $120{ }^{\circ} \mathrm{C}$. The changes in the $\delta^{18} \mathrm{O}$ value of $\mathrm{H}_{2} \mathrm{O}$ and in the $\mathrm{HCl} / \mathrm{H}_{2} \mathrm{O}$ ratio of the vapor phase are shown as a subhorizontal line in Figure 11, in which the X-axis is the ScF of $\mathrm{HCl}$ in the $\mathrm{HCl}-\mathrm{H}_{2} \mathrm{O}$ binary system, which is defined by:

$$
\mathrm{ScF}(\mathrm{HCl})=\frac{1000 \mathrm{C}_{\mathrm{HCl}}}{1000 \mathrm{C}_{\mathrm{HCl}}+\mathrm{C}_{\mathrm{H}_{2} \mathrm{O}}}
$$

$\mathrm{HCl}$ in the vapor phase is effectively removed by the condensed liquid phase. Most of the $\mathrm{HCl}$ was lost by the time that $20 \%$ of the water vapor had condensed. The above compositional trend does not always explain the distribution of data points for the gases from site $\mathrm{J}$.

We assume the following condition for the second case of condensation. Within a conduit filled with volcanic gas, a condensed liquid phase is likely to be dominant. The liquid phase is likely to be strongly acidic due to the absorption of $\mathrm{HCl}$ from the vapor phase; consequently, the removal of $\mathrm{HCl}$ from the vapor phase is suppressed because $\mathrm{K}$ is the equilibrium constant of the following reaction:

$$
\mathrm{H}^{+}+\mathrm{Cl}^{-}=\mathrm{HCl}(\text { gas })
$$

Two cases of condensation were assumed, where the $\mathrm{pH}$ of the coexisting liquid phase is -0.3 or -0.9 . When the $\mathrm{pH}$ of the condensed liquid phase is fixed, the change in the $\mathrm{HCl} / \mathrm{H}_{2} \mathrm{O}$ ratio of the vapor phase is given by:

$$
m=m_{i} \mathrm{~F}^{\gamma}
$$

where,

$$
\gamma=\frac{10^{p H}}{\mathrm{~K}}-1
$$

The trend in the composition with progressive condensation is given in Figure 11. Most of the data points for the gases from site J are distributed within the two curves. The composition of the hot spring waters at site $\mathrm{J}$ is also shown. Most of the data points for the hot spring water are distributed along the direct mixing curve between the MV and the LMW.

\section{Conclusions}

Based on the composition of the gases from site $\mathrm{J}$, the AET reached a peak in May 1999. This period with high AET followed the period of intense earthquakes, which suggests that magma movement was followed by magma degassing, which may have increased the flux and speed of the gas ascent through the conduit to the surface. The temperature of magmatic vapor at site $\mathrm{J}$ was estimated at $252{ }^{\circ} \mathrm{C}$ to $370{ }^{\circ} \mathrm{C}$, based on the enthalpy and isotope ratio of the gas. During the ascent, contamination by groundwater was limited, which suggests the existence of a welldeveloped inner wall of the gas conduit, which prevents the intrusion of groundwater. During the ascent of the magmatic gas to the surface, the enthalpy of the gas would have been lost by conduction through the wall of the conduit. The magmatic gas would have ascended a large distance from the deep source to the surface, which is consistent with the findings of a magnetotelluric survey [Aizawa et al. 2009] that revealed an electrically resistive body beneath the geothermal area at site $\mathrm{J}$, at depths of 0.5 $\mathrm{km}$ to $3.0 \mathrm{~km}$. The resistive body was interpreted to be a solidified intrusive magma. The gas was probably transported through the solidified magma.

The correlations among the $\delta^{18} \mathrm{O}$ values of $\mathrm{H}_{2} \mathrm{O}$, $\mathrm{CO}_{2} / \mathrm{H}_{2} \mathrm{O}$ and $\mathrm{HCl} / \mathrm{H}_{2} \mathrm{O}$ suggest that the gases at site $\mathrm{J}$ experienced partial condensation of the water vapor. During condensation, a strongly acidic liquid phase would have coexisted with the vapor phase, preventing the absorption of $\mathrm{HCl}$ in the vapor phase by the liquid phase. The strongly acidic liquid phase might have originated from the condensed liquid phase.

The $\mathrm{CO}_{2} / \mathrm{H}_{2} \mathrm{O}$ ratio of the magmatic gas was estimated as 0.008 , which is much lower than the 0.028 observed for magmatic gas sampled from the erupting Unzen volcano in 1992 [Ohba et al. 2008]; this suggests that the degassing magma beneath Onawashiro crater is depleted in $\mathrm{CO}_{2}$ relative to the magma of Unzen volcano.

The fumarolic gas sampled at site A might be a steam phase generated by the mixing of magmatic gas and groundwater. The fumarolic gases at sites $\mathrm{U}, \mathrm{K}$ and $\mathrm{H}$ showed significant condensation of water vapor. The addition of water vapor derived from groundwater would have occurred prior to the condensation.

The $\mathrm{N}_{2}$-He-Ar compositions of the gases from site $\mathrm{J}$ suggests that the magmatic component is identical to that of andesitic volcanoes above a subduction zone. The correlation between the ${ }^{3} \mathrm{He} /{ }^{4} \mathrm{He}$ and ${ }^{4} \mathrm{He} /{ }^{20} \mathrm{Ne}$ ratios in the fumarolic gases suggests that the gases at site $\mathrm{J}$ contain an end member for which the ${ }^{3} \mathrm{He} /{ }^{4} \mathrm{He}$ ratio is as high as $5(\mathrm{R} / \mathrm{Ra})$. The correlation between the $\delta^{13} \mathrm{C}$ value of $\mathrm{CO}_{2}$ and the $\mathrm{CO}_{2} /{ }^{3} \mathrm{He}$ ratio suggests that the origin of the $\mathrm{CO}_{2}$ in the gases from site J was mainly limestone, with a minor component of MORBtype $\mathrm{CO}_{2}$.

The hot spring waters discharged at site $\mathrm{J}$ comprise a direct mixture of MV and LMW.

Acknowledgements. We sincerely thank Dr. Mauro Martelli for his constructive review of the manuscript, and Dr. Salvo Inguaggiato for the editorial handling of the manuscript. 


\section{References}

Aizawa, K., Y. Ogawa, M. Mishina, K. Takahashi, S. Nagaoka, N. Takagi, S. Sakanaka and T. Miura (2009). Structural controls on the 1998 volcanic unrest at Iwate volcano: Relationship between a shallow, electrically resistive body and the possible ascent route of magmatic fluid, J. Volcanol. Geotherm. Res., 187, 131-139.

Coleman, M.L., T.J. Shepherd, J.J. Durham, J.E. Rouse and G.R. Moore (1982). Reduction of water with zinc for hydrogen isotope analysis, Anal. Chem., 54, 993-995.

Epstein, S. and T.K. Mayeda (1953). Variation of ${ }^{18} \mathrm{O}$ content of waters from natural sources, Geochim. Cosmochim. Acta, 4, 213-224.

Giggenbach, W.F. (1980). Geothermal gas equilibria, Geochim. Cosmochim. Acta, 44, 2021-2032.

Giggenbach, W.F. (1987). Redox processes governing the chemistry of fumarolic gas discharges from White Island, New Zealand, Appl. Geochem., 2, 143-161.

Giggenbach, W.F. and R.L. Goguel (1989). Collection and analysis of geothermal and volcanic water and gas discharges, CD 2401, Chemistry Division, Department of Scientific and Industrial Research (DSIR), Petone, New Zealand.

Giggenbach, W.F. (1992). Isotopic shifts in waters from geothermal and volcanic systems along convergent plate boundaries and their origin, Earth Planet. Sci. Lett., 113, 495-510.

Giggenbach, W.F. (1997). The origin and evolution of fluids in magmatic-hydrothermal systems, In: H.L. Barnes (Editor), Geochemistry of Hydrothermal Ore Deposit, pp. 737-796.

Horita, J. and D.J. Wesolowski (1994). Liquid-vapor fractionation of oxygen and hydrogen isotopes of water from the freezing to the critical temperature. Geochim. Cosmochim. Acta, 58, 3425-3437.

Itoh, J. and N. Doi (2005). Geological map of Iwate volcano, Geological survey of Japan, AIST.

Kazahaya, K., M. Yasuhara, T. Sato, M. Takahashi and A. Marui (2000). Isotope altitude effect for groundwaters in the Iwate volcano and Kakkonda areas, Rept. Geol. Surv. Japan, 284, 57-67. (Japanese with English abstract) Kusakabe, M. (2001). A simple method for sampling total dissolved carbonate in carbonate-rich natural waters and $\mathrm{CO}_{2}$ preparation for $\delta^{13} \mathrm{C}$ determination, Geochem. J., 35, 459-464.

Marty, B., A. Jambon and Y. Sano (1989). Helium isotopes and $\mathrm{CO}_{2}$ in volcanic gases of Japan, Chem. Geol., 76, $25-40$.

Miura, S., S. Ueki, T. Sato, K. Tachibana and H. Hamaguchi (2000). Crustal deformation associated with the 1998 seismo-volcanic crisis of Iwate volcano, northeastern Japan, as observed by a dense GPS network, Earth Planet Space, 52, 1003-1008.
Noguchi, K., S. Ueno, M. Ichikuni and T. Goto (1961). Chemical composition of fumarolic gases obtained from volcano Iwate, Bull. Volcanol. Soc. Japan, 5, 293-298.

Ohba, T. (2007). Formation process of recent fumarolic gases at the Mt. Mihara summit peak of the Izu-Oshima volcano, Japan, Earth Planet Space, 59, 1127-1133.

Ohba, T., J. Hirabayashi, K. Nogami, M. Kusakabe and M. Yoshida (2008). Magma degassing process during the eruption of Mt. Unzen, Japan in 1991 to 1995: Modeling with the chemical composition of volcanic gas, J. Volcanol. Geotherm. Res., 175, 120-132.

Ohba, T., T. Sawa, N. Taira, T. F. Yang, H.F. Lee, T.F. Lan, M. Ohwada, N. Morikawa and K. Kazahaya (2010). Magmatic fluids of Tatun volcanic group, Taiwan, Appl. Geochem., 25, 513-523.

Ohwada, M., T. Ohba, J. Hirabayashi, K. Nogami, K. Nakamura and K. Nagao (2003). Interaction between magmatic fluid and meteoric water, inferred from ${ }^{18} \mathrm{O} /{ }^{16} \mathrm{O}$ and ${ }^{36} \mathrm{Ar} / \mathrm{H}_{2} \mathrm{O}$ ratios of fumarolic gases at the KusatsuShirane volcano, Japan, Earth Planet Space, 55, 105-110.

Ozawa, T. (1968). Chemical analysis of volcanic gases: I. Chemical analysis of volcanic gases containing water vapor, hydrogen chloride, sulfur dioxide, hydrogen sulfide, carbon dioxide, etc, Geochem. Int., 5, 939-947.

Poreda, R. and H. Craig (1989). Helium isotope ratios in circum-Pacific volcanic arcs, Nature, 338, 473-478.

Sano, Y. and B. Marty (1995). Origin of carbon in fumarolic gas from island arcs, Chem. Geol., 119, 265-274.

Simonson, J. M. and D. A. Palmer (1993). Liquid-vapor partitioning of $\mathrm{HCl}(\mathrm{aq})$ to $350{ }^{\circ} \mathrm{C}$, Geochim. Cosmochim. Acta, 57, 1-7.

Tanaka, S., H. Hamaguchi, T. Nishimura, T. Yamawaki, S. Ueki, H. Nakamichi, T. Tsutsui, H. Miyamachi, N. Matsuwa, J. Oikawa, T. Ohminato, K. Miyaoka, S. Onizawa, T. Mori and K. Aizawa (2002). Three-dimensional Pwave velocity structure of Iwate volcano, Japan from active seismic survey, Geophys. Res. Lett., 29, 10.1029/2002GL014983.

Taran, Y.A., B.G. Pokrovsky and Y.M. Doubik (1989). Isotopic composition and origin of water from andesitic magmas, Dokl. Acad. Sci. USSR, 304, 440-443. (in Russian).

\footnotetext{
${ }^{\star}$ Corresponding author: Takeshi Ohba,

Tokai University, School of Science, Department of Chemistry,

Kanagawa, Japan; e-mail: takeshi_ohba@tokai-u.jp.
}

(C) 2011 by the Istituto Nazionale di Geofisica e Vulcanologia. All rights reserved. 